Original Paper http://ajol.info/index.php/ijbcs http://indexmedicus.afro.who.int

\title{
Prediction of the potential invasion of Lantana Camara L. (Verbenaceae) an exotic plant species in Côte d'Ivoire from a modeling approach
}

\author{
Franck Placide Junior PAGNY ${ }^{1}$, Ouattara MEVANLY ${ }^{1,2}$, \\ N'Gouan Emmanuel Joël ABROU ${ }^{1}$ and Marie-Solange TIÉBRÉ ${ }^{1,2 *}$
}

\author{
${ }^{1}$ Laboratory of Natural Environments and Biodiversity Conservation, UFR Biosciences, University Félix \\ Houphouët-Boigny, 22 BP 582 Abidjan 22, Côte d'Ivoire. \\ ${ }^{2}$ Laboratory of Systematic, Herbarium and Botanical Museum, National Floristic Center, University Félix \\ Houphouët-Boigny, 22 BP 582 Abidjan 22, Côte d'Tvoire. \\ *Corresponding author; E-mail: tiebrems@hotmail.com; Tel: (00225) 07578737
}

\begin{abstract}
Invasive alien plant species represent a great threat to the integrity of ecosystems. Acquiring information on the dynamics of these species on a cartographic basis constitutes a tool for their sustainable management. Among these species, Lantana camara L., known for its environmental and agronomic impacts, is currently reported in several localities of Côte d'Ivoire. The general objective of this study is to model the ecological niche of this species over the entire country. To do so, 89 points occurrences and 19 current and future bioclimatic variables were collected to model the potential distribution of this species on the basis of the RCP 8.5 scenario as part of the HadGEM2-ES climate model. This is $75 \%$ of presence data (67 points) used for model calibration and $25 \%$ (22 points) for testing. At the end of the modeling carried out with the MaxEnt software, the areas suitable for the species are characterized by low temperatures and heavy rainfall., under current climatic conditions, approximately $65,782.40 \mathrm{~km}^{2}$, or $20 \%$ of the national territory, is suitable for the invasion of $L$. camara. Azagny National Park, Banco National Park, and the Iles Nature Reserve Ehotiles have distributions with high probability of the presence of the species. By 2050, the climate projects high temperatures and low precipitation in the future. The results show that by adapting to this new climatic range, the L. camara proliferation area will increase to $78,036.05 \mathrm{~km}^{2}$, or $24 \%$ of the national territory. An upward trend, with a rate of change of 18.6, has been observed in the favorable areas of this area. To maintain the normal functioning of ecosystems and the sustainability of ecosystem services, the areas that have been identified as the most vulnerable to the invasion of L. camara must be the subject of control strategies of this species.
\end{abstract}

(C) 2020 International Formulae Group. All rights reserved.

Keywords: Lantana camara, Species modeling, MaxEnt, Côte d'Ivoire, RCP scenario 8.5.

\section{INTRODUCTION}

Increased trade and the flow of goods around the world are behind the introduction of several species outside their natural range (Hulme et al., 2008). While most of them are difficult to persist, a few can behave much more dynamically. They then develop large populations, compete with native species and alter the functioning of ecosystems (Vanderhoeven et al., 2007). They are called Invasive Exotic Species (IAS) or invasive species. These species are currently at the heart 
of concerns because of the threat they pose to the biodiversity, ecosystems and economy of countries (Gooden et al., 2009). Indeed, they cause worldwide ecological damage and economic losses estimated in tens of billions of dollars per year (Perrings et al., 2000; Born et al., 2005; Paini et al., 2016).

The problem of invasive alien plant species is worrying in the current context of global warming (Hellmann et al., 2008). Indeed some authors emphasize the potential effect of global warming on biological processes because many invasive alien species adapt to a series of environmental conditions. This is the case in Nepal where the work of Shrestha et al. (2018) have shown an increase in the distribution area of several invasive plants due to their resilience to climatic variations. There were Ageratum houstonianum Mill. (Compositae); Chromolaena odorata (L.) R. M. King \& H. Rob. (Compositae); Hyptis suaveolens (L.) Poit. (Lamiaceae); Mikania micrantha Kunth. (Compositae) and Parthenium hysterophorus L. (Compositae). Similarly, in Sri Lanka, the expansion of Panicum maximum Jacq. (Poaceae) following climate change continues to be remarkable in various ecosystems (Kariyawasam et al., 2019).

Given the many negative impacts of these invasive species on ecosystems and the sustainability of ecosystem services, their control has become a priority for biodiversity conservation planners and country governments (Smith et al., 2006). Sustainable management of invasive alien species requires identifying habitats favorable to the proliferation of these species in order to slow their expansion. Several authors have thus developed prevention and control tools, in particular modeling studies to monitor the dynamics of these invasive plants (Padalia et al., 2014). According to Qin et al. (2015), modelling the distribution of invasive plants permits their monitoring as it identifies and predicts areas likely to be invaded by invasive alien plant species.
Lantana camara $\mathrm{L}$. is known for its environmental and agronomic impacts on ecosystems (Taylor et al., 2012). It is a shrub native to the American tropics and one of the worst weeds in the world (IUCN, 2000). It was introduced in the mid-19th century in the tropical regions of Africa, Asia and Oceania as an ornamental (Day et al., 2003). The Global Invasive Species Information Network now identifies $L$. camara among the top ten invasive species in the world (GISIN, 2011). This species leads to the reduction of the diversity of invaded biotopes, the extinction of native species and the deterioration of the physicochemical properties of the soil (Mandal and Joshi, 2014). It encroaches on agricultural land, reduces the carrying capacity of pastures and poses a threat to many crops (Baars and Heystek, 2003). Numerous studies on the modeling of the distribution of L. camara have been carried out worldwide to monitor its expansion. Examples include the work of Priyanka and Joshi (2013) in India who predicted the distribution of the species in the western Himalayan regions. Taylor and Kumar (2013) have shown its potential distribution in Queensland, Australia. The impact of climate change on the distribution of L. camara at the level of small island ecosystems in Fiji in Oceania was assessed by Taylor and Kumar (2014). Qin et al. (2016) estimated the potential distribution of this species worldwide. As for Mungi et al. (2018), they analyzed the impact of climate change on its distribution in the Himalayas. In Africa, the work of Fandohan et al. (2015) analyzed the distribution of this species in the protected areas of Benin. Analysis of these different works has shown an increase in the range of the species.

Currently, L. camara is reported from several localities in Côte d' Ivoire (Alépé, Bongouanou, Dimbokro, Gagnoa, GrandBassam and Issia), (Kassi et al., 2010 ; Maroun, 2017 ; Tiébré et al., 2018). It was introduced by horticulture (Neuba et al., 2014). To date, the current and future distribution of L. camara in Côte d' Ivoire wasn't analyzed. In order to 
provide reliable scientific data on the potential distribution of this species in the various ecosystems of the country, the following questions were asked: What are the bioclimatic factors and the models likely to predict the distribution of Lantana camara in Côte d' Ivoire ? What are the ecological characteristics of $L$. camara ? What is the current and future distribution of this species on Ivorian territory ? To address these concerns, the main objective of this study is to model the ecological niche of Lantana camara across the Côte d'Ivoire. Specifically, it involved (1) testing the performance of the MaxEnt model for predicting the distribution of L. camara, (2) characterizing the bioclimatic variables determining the modeling of the distribution of the species, (3) describe the current and future ecological characteristics of the species and, (4) assess its dynamics of potential distribution on the Ivorian territory. The following hypotheses have been put forward: (1) the MaxEnt model is effective in predicting the current and future distribution of L. camara over the territory of Côte d'Ivoire ; (2) there are determining bioclimatic variables in the modeling of the distribution of L. camara; (3) this species can adapt to different environmental conditions.

\section{MATERIALS AND METHODS \\ Study zone}

Côte d'Ivoire is located in West Africa, between $4^{\circ} 30^{\prime}$ and $10^{\circ} 30^{\prime}$ north latitude and $2^{\circ} 30^{\prime}$ and $8^{\circ} 30^{\prime}$ west longitude. It covers an area of $322,462 \mathrm{~km}^{2}$ and has 22671331 (RGPH, 2014). The country is bordered on to the west by Liberia and Guinea Conakry, to the north by Mali and Burkina Faso, to the east by Ghana and to the south by the Atlantic Ocean (Figure 1). Located in the transition zone between the humid equatorial climate and the dry tropical climate, Côte d'Ivoire is characterized by annual average temperatures which vary between 21 and $31{ }^{\circ} \mathrm{C}$ and an average annual rainfall between 1100 and 2500 $\mathrm{mm}$ (Kassin et al., 2008). With regard to vegetation, there are two main areas: the Sudanese area located north of the 8th parallel, consisting of open forests, Sudanese and Subsudanese savannahs, and the Guinean area consisting of dense evergreen moist forests, dense moist forests semi-deciduous and a forest-savanna mosaic (Guillaumet and Adjanohoun, 1971). Agriculture affirms its primacy in the economic activity of Côte d'Ivoire. It is marked by the domination of the "coffee-cocoa" binomial which represents $40 \%$ of export earnings and 20\% of Gross Domestic Product (Sangare et al., 2009).

\section{Morphological and biological characteristics of Lantana camara}

Lantana camara, is a species belonging to the class of Magnoliopsida, the order of lamiae and the family of Verbenaceae (Sharma et al., 2005). It is a deciduous shrub, covered with pointed and rigid hairs and with several stems with an average height of $2 \mathrm{~m}$. The stems have a square cross section and a diameter of $24 \mathrm{~mm}$ when they are young. They become more rounded, gray or brown and reach 150 $\mathrm{mm}$ in diameter at maturity. The inflorescence can be yellow, orange, white, pale purple, pink or red (Figure 2). The flowers are small, multicolored, in clusters and flat, reaching $4 \mathrm{~cm}$ in diameter. The fruit of the species is a round, fleshy, green, hard drupe when young, turning purple or black at maturity (Sharma et al., 2005). The species generally grows best in environments such as wasteland, edges of tropical forests, beaches, agricultural areas, meadows, riparian areas, scrub, urban areas, pastures, protected areas and forests in regeneration (Sharma et al., 2005). According to Sharma et al. (2005), the species has a vegetative mode of reproduction which is stratification. In fact, the horizontal stems produce roots each time they met the soil, eventually giving a new plant. Besides this, there is sucking where the severed stems can take root if they are covered with moist soil, dead leaves or debris. Then the stems can develop roots and develop into plants (Day et 
al., 2003). High seed production, which often gives it a competitive advantage over native species, is at the origin of the rapid colonization of the environment (Sharma et al., 2005). Likewise, the secretion of "allelopathic substances" such as triterpenes which inhibit the growth of neighboring plants is a functional feature of the invasiveness of the species (Sharma et al., 2005). In addition, the homeostatic physical form which describes the capacity of an individual or a population to maintain a relatively constant physical form in various environments and the phenotypic plasticity which is the capacity of a genotype to modify its growth and its development in response to environmental changes also increases the invasiveness of $L$. camara (Sharma et al., 2005).

\section{Collection of data}

For this study, three categories of occurrence points were used (Figure 1). There were forty-four occurrence points of Lantana camara collected from field missions. We also used seven occurrence points from published articles and theses (Traoré and Péné, 2016). We completed our data with thirty-eight occurrence points from Global Biodiversity Information Facility (GBIF) at https://www.gbif.org/. All these data made it possible to draw up a list of occurrence points for Lantana camara.

The environmental parameters used were climatic variables (precipitation and temperature). Current climate data (1950 $2000)$ and future climate projections (20002050) were obtained from Worldclim website (https:/www.worldclim.org) with a resolution of 30 seconds (spatial resolution of approximately $1 \mathrm{~km}^{2}$ in West Africa). These data include 19 bioclimatic variables (Table 1) derived from temperature and precipitation (Yi et al., 2018). The future projection for 2050 was established according to the RCP 8.5 scenario (Meinshausen et al., 2011). RCP 8.5 is an third generation scenario and is been preferred by Special Report on Emissions
Scenarios (SRES) because it allow more flexibility in modeling processes (IPCC, 2013). For this scenario, temperature is projected to rise level by $2{ }^{\circ} \mathrm{C}$ in West Africa by mid- $21^{\text {st }}$ century, with atmospheric $\mathrm{CO} 2$ over $550 \mathrm{ppm}$ (IPCC, 2013). This scenario is an improved version of scenario A.2. It was chosen because it predicts the most divergent trends for the region of West Africa compared to other scenarios (IPCC, 2013). It was used in several studies on West African ecosystems (Meinshausen et al., 2011). The Met Office climate model (HadGEM2-ES) was also used (Meinshausen et al., 2011). This model is chosen because its currently the most suitable for simulating climate responses in West Africa (Fandohan et al., 2015). Furthermore, this model corresponded to the studies of invasive alien plant because it imply impacts, adaptation, and vulnerability (IPCC, 2013).

\section{Data analysis and processing Modeling process and model validation}

MaxEnt V3.3.3 k software was used to model suitable habitats for L. camara. In order to ensure the final model's quality, the environmental variables were subjected to correlation test to select the least correlated ones $(r<0.80)$ taking into account the biases that strong correlations have on the predictions. For this, the R software was used (Fukushima, 2013). This value $(r<0.80)$ was chossen because its takes into consideration species ecology and the extreme environmental conditions (Priyanka et Joshi, 2013; Djotan et al., 2018 ; Mungi et al., 2018).

Modeling was performed using occurrence points of Lantana camara and current and future bioclimatic variables into the Maxent software (Gbesso et al., 2013). Analysis in Maxent program was performed using $75 \%$ of presence data for model calibration and 25\% for testing (Diarrassouba et al., 2019). Maxent algorithm graphical interface is equipped with several features aiding the interpretation and validation of the model, namely AUC plots, Jackknife test plots 
and response curves (Phillips et al., 2006). Maxent generates maps that estimate the probability of occurrence of the species in a range of 0 to 1 , where 0 is the lowest and 1 is the highest probability (Phillips et al., 2006). The maps obtained is used to assess the impact of climate change on the distribution of the model species (Gnagbo et al., 2015).

The AUC scores are interpreted as reflecting the ability of the model to distinguish presence data from background data (Phillips et al., 2006). The AUC values have been interpreted as proposed by Hernandez et al. (2006): For AUC $0.50<$ AUC $<0.60$, the model is invalid ; for AUC $0.60<\mathrm{AUC}<0.70$, the model is bad; for $0.7<\mathrm{AUC}<0.8$, the model is acceptable ; for $0.8<$ AUC $<0.9$, the model is excellent and for AUC> 0.9, the model is exceptional. A Jackknife test was also carried out on bioclimatic variables to determine which ones contribute the most to modeling (Bargain and Fabri, 2016). According to these authors, for each environmental variable, the green bar shows by how much the total contribution of the variables is reduced if this specific variable is excluded from the analysis. As for the blue bar, it indicates the proportion of all the contributions of the variables if a variable is used in isolation and the remaining variables are excluded from the analysis. Also, the response curves of the bioclimatic variables were analyzed to describe the ecological characteristics of L. camara. Indeed, a horizontal curve shows that the species does not really have a preference for a given variable. Then, an increasing curve shows an affinity of the species for the largest values of this variable. Then, a decreasing curve shows an affinity of the species for the low values of the variable and finally, a unimodal curve shows an affinity for a certain range of values of the variable (Bargain and Fabri, 2016). All these analyzes were carried out using MaxEnt software.

Arcgis 10.1 software was used to map the current and future geographic distribution of the habitat favorable to the species (Imorou,
2020). The map of the national network of protected areas of Côte d'Ivoire (Asseh et al., 2019) has been superimposed on the potential distribution maps of $L$. camara. This overlapping made it possible to assess the current and future vulnerability of the national network of protected areas to the invasion of this species.

The different habitat levels of the model species were classified using the logistic probability of presence thresholds generated by the model. The logistic probability of occurrence of a species is considered to be an indicator of the quality of habitats for the species (Liu et al., 2005). The logistic probability was obtained in the cumulative format which gives a probability of occurrence between 0 and 1 . It was classified into 5 classes: (i) for a value less than 0.19 , the probability of the presence of model species is very weak ; (ii) for that between [0.19-0.339[, the probability of presence is low ; (iii) value between [0.339-0.479[, the probability of presence is moderate ; (iv) value between [0.479-0.62[, the probability of presence is high ; and (v) for a value greater than 0.62 , the probability of presence is very high (Priyanka and Joshi, 2013).

The extent of each habitat level (area and percentage), both under current and future conditions was estimated in order to assess the gain or loss of the potentially favorable area of the species at scale from Ivory Coast. This estimate was made using the spatial analyst tool in ArcGis software.

The rates of change (Tc) from currently favorable habitats to potentially favorable habitats or not in the future and vice versa were estimated using the following formula, previously used by N'Guessan et al. (2019) : Tc $=((\mathrm{A} 2-\mathrm{A} 1) / \mathrm{A} 1) \times 100$ with $\mathrm{A} 1$ and $\mathrm{A} 2$ which respectively represent the initial area (current climatic condition) and final (future climatic condition) of presence of the species. The positive values of $\mathrm{Tc}$ indicate a gain in the area of the habitat while the negative values correspond to a loss of surface. 


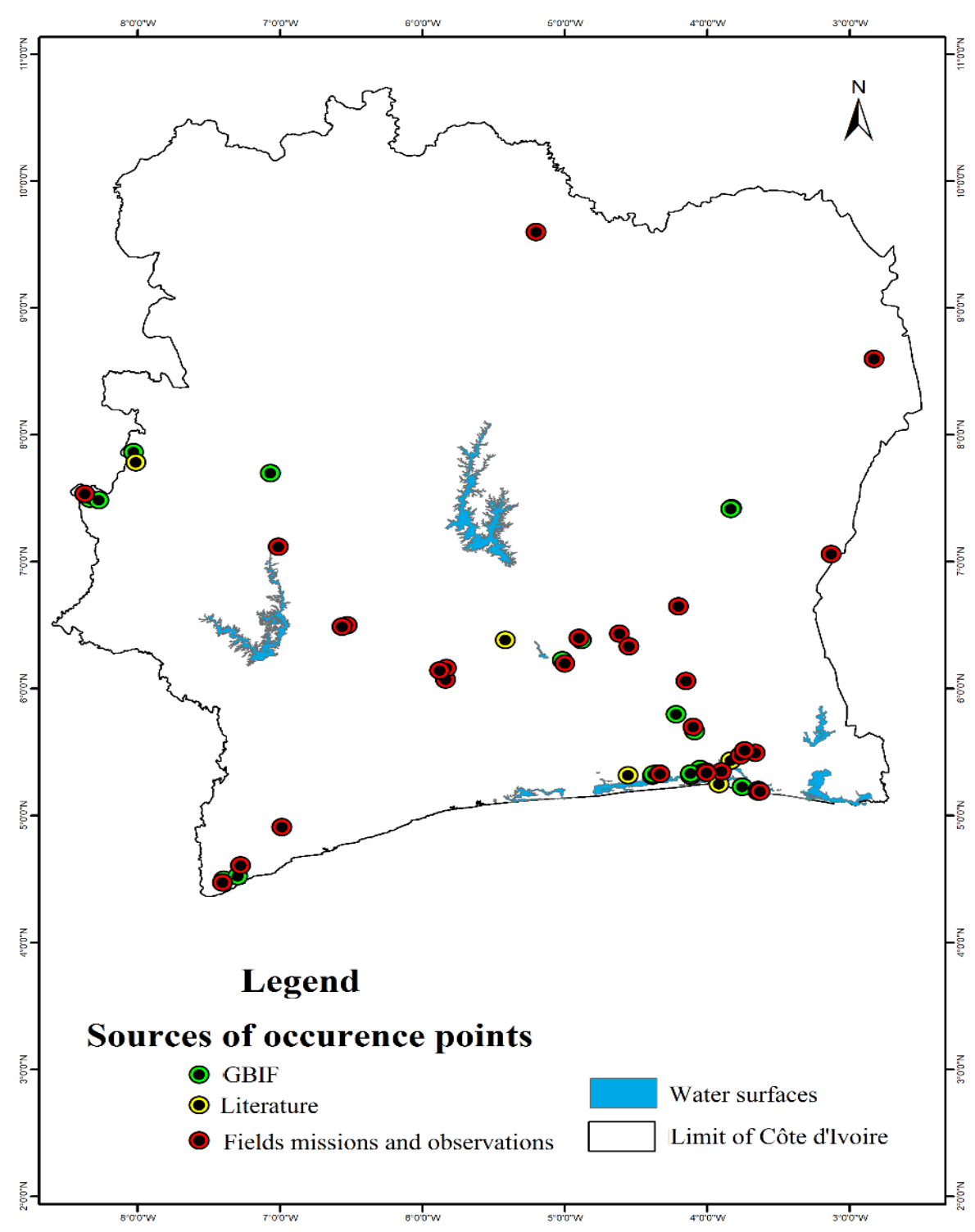

Figure 1: Study area along with occurrence points of Lantana camara. 


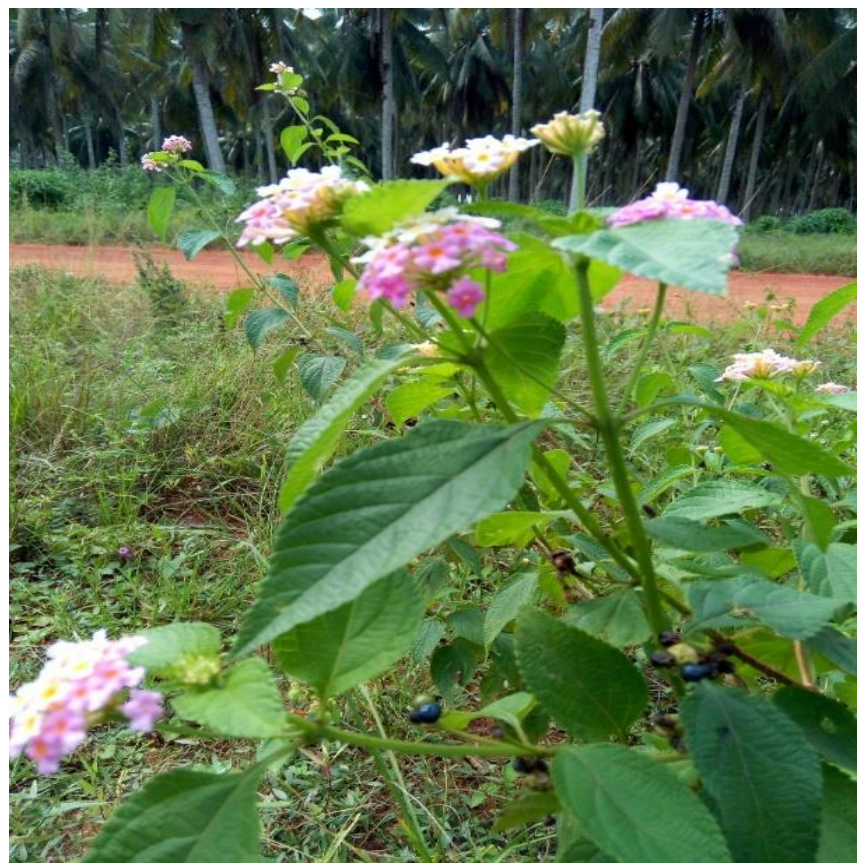

Figure 2: Leaves, stem, fruits and flowers of Lantana camara.

Table 1: Bioclimatics variables used for Maxent test.

\begin{tabular}{|c|c|}
\hline Abbreviation & Description \\
\hline BIO 1 & Annual Mean Temperature $\left({ }^{\circ} \mathrm{C}\right)$ \\
\hline BIO 2 & Mean Diurnal Range (Mean of monthly (max temp-min temp)) $\left({ }^{\circ} \mathrm{C}\right)$ \\
\hline BIO 3 & Isothermally (Bio1/Bio7) $(\times 100)$ \\
\hline BIO 4 & Temperature Seasonality (standard deviation*100) (C of V) \\
\hline BIO 5 & Max Temperature of Warmest Month $\left({ }^{\circ} \mathrm{C}\right)$ \\
\hline BIO 6 & Min Temperature of Coldest Month $\left({ }^{\circ} \mathrm{C}\right)$ \\
\hline BIO 7 & Temperature Annual Range (Bio5-Bio6) $\left({ }^{\circ} \mathrm{C}\right)$ \\
\hline $\mathrm{BIO} 8$ & Mean Temperature of Wettest Quarter $\left({ }^{\circ} \mathrm{C}\right)$ \\
\hline BIO 9 & Mean Temperature of Driest Quarter $\left({ }^{\circ} \mathrm{C}\right)$ \\
\hline BIO 10 & Mean Temperature of Warmest Quarter $\left({ }^{\circ} \mathrm{C}\right)$ \\
\hline BIO 11 & Mean Temperature of Coldest Quarter $\left({ }^{\circ} \mathrm{C}\right)$ \\
\hline BIO 12 & Annual Precipitation (mm) \\
\hline BIO 13 & Precipitation of Wettest Month (mm) \\
\hline BIO 14 & Precipitation of Driest Month (mm) \\
\hline BIO 15 & Precipitation Seasonality (C of V) \\
\hline BIO 16 & Precipitation of Wettest Quarter (mm) \\
\hline BIO 17 & Precipitation of Driest Quarter (mm) \\
\hline BIO 18 & Precipitation of Warmest Quarter (mm) \\
\hline BIO 19 & Precipitation of Coldest Quarter (mm) \\
\hline
\end{tabular}




\section{RESULTS}

\section{Model validation and contribution of bioclimatic variables}

Given the AUC value of around 0.877 for current climatic conditions (Figure 3) and 0.861 for future climatic conditions, by 2050 (Figure 4), the performance of the modeling performed is judged excellent.

Under current climatic conditions, the variables that most contribute to the modelling are BIO 3 (Isothermally (BIO 1/BIO 7) $(\times 100)$ ), BIO 5 (Max Temperature of Warmest Month), BIO 7 (Temperature Annual Range (BIO 5-BIO 6)), BIO 8 (Mean Temperature of Wettest Quarter), BIO 16 (Precipitation of Wettest Quarter), BIO 18 (Precipitation of Warmest Quarter), (Table 2). For the Jackniffe test, $\mathrm{BIO} 3$ and $\mathrm{BIO} 7$ are the variables which most contributed to the model (Figure 5).

Under future climatic conditions, the variables that most contribute to the modelling are BIO 8 (Mean Temperature of Wettest Quarter) ; BIO 9 (Mean Temperature of Driest Quarter) ; BIO 10 (Mean Temperature of Warmest Quarter) ; BIO 15 (Precipitation Seasonality (C of V)) ; BIO 17 (Precipitation of Driest Quarter) ; and BIO 18 (Precipitation of Warmest Quarter), (Table 2). For the Jackniffe test, BIO 15 and BIO 17 are the variables which most contributed to the model (Figure 6).

\section{Ecological characteristics of Lantana camara}

Indeed, there is a positive correlation between the suitability of the habitat for $L$. camara and the average Mean Temperature of Wettest Quarter (BIO 8) which varies from 22 to $28.5^{\circ} \mathrm{C}$ (Figure 7a). The temperature Annual Range (BIO 7) of L. camara is 7.8 to $16{ }^{\circ} \mathrm{C}$ (Figure 7b). Lantana camara has an affinity for the values of isothermality (BIO 3), between 57 and 80 (Figure $7 \mathrm{c}$ ). This species also prefers max Temperature of Warmest Month (BIO 5) varying from 28.4 to $35{ }^{\circ} \mathrm{C}$ (Figure $7 \mathrm{~d}$ ). There is also a positive relationship between the suitability of the habitat for L. camara and the precipitation for the Precipitation of Wettest Quarter (BIO 16) between 380 and $1040 \mathrm{~mm}$ (Figure 7e), as well as the precipitation of
Warmest Quarter (BIO 18) varying from 120 to $590 \mathrm{~mm}$ (Figure 7f). Under current climatic conditions, areas of low temperatures and heavy rainfall constitute habitats favorable to the proliferation of L. camara.

The response curves of the variables to the prediction of the species under future climatic conditions were also generated. Thus, L. camara has an affinity for precipitation of Driest Quarter (BIO 17) between 10 and 430 mm (Figure 8a). Similarly, L. camara has an affinity for a precipitation Seasonality (BIO15) ranging from 40 to 130 (Figure $8 \mathrm{~b}$ ). In addition, L. camara requires an average mean Temperature of Driest Quarter (BIO 9) of between 24.5 and $30.8{ }^{\circ} \mathrm{C}$, as well as an average mean Temperature of Wettest Quarter (BIO 8) ranging from 22, 3 at $31.2{ }^{\circ} \mathrm{C}$ (Figures $8 \mathrm{c}$ and $8 \mathrm{~d}$ ). Furthermore, there is a negative correlation between the suitability of the habitat for L. camara and the average mean Temperature of Warmest Quarter (BIO 10) varying from 25.1 to $32.5{ }^{\circ} \mathrm{C}$ (Figure 8e), as well than the precipitation of Warmest Quarter (BIO 18) between 70 and $470 \mathrm{~mm}$ (Figure 8f). These results show that the climate projects low rainfall in the future which will also be favorable for the proliferation of L. camara.

\section{Dynamics of potential distribution of Lantana camara}

The modeling show that the habitats currently favorable to the proliferation of $L$. camara have been found to be distributed in the south of the country. The most favorable areas are concentrated along the littoral zone in contact with the Atlantic Ocean, from the region of San-Pédro in the southwest to the Ghanaian border, in the southeast of the country (Figure 9). Protected areas such as Azagny National Park, Banco National Park, and the Ehotile Islands Natural Reserve located in this part of the country show a distribution with high probability of the presence of the species. In addition, the Tai National Park does not constitute a habitat favorable to the proliferation of L. camara. However, there is a low probability of the species being present south of this park. In contrast, the north of Côte d'Ivoire is an area characterized by a very low 
probability of the presence of the species. According to forecasts of the distribution by 2050 , the habitats favorable to the proliferation of $L$. camara will not experience a decline and will always remain in the southern part of the country (Figure 10), but this time with a slight increase in the area of all classes of favorable areas for L. camara (Figure 11). The probability of the presence of the species will always remain very high in the Azagny National Park, the Banco National Park and the Ehotliés Islands Nature Reserve. During this period, almost the southern half of the Tai National Park could face a moderate presence of L. camara.

The projections in future climates having revealed a shift in the climatic envelope of the species, L. camara could experience a very restricted distribution in the center and east of the country with a moderate probability of presence of the species as in south of the Marahoué National Park. Furthermore, the analysis of the extent of the different levels of habitats favorable to the species, indicates that approximately $65,782.40 \mathrm{~km}^{2}$, or $20 \%$ of the national territory, are currently favorable to the proliferation of Lantana camara (Table 3). As for the area potentially unfavorable to the distribution of the species, it covers $256,680.70$ or $80 \%$ of the territory. By 2050 , projections have revealed an increase in the rate of change $(+18.6)$ in the area potentially favorable for the species. It went from $65,782.40 \mathrm{~km}^{2}$ (current weather conditions) to $78,036.05 \mathrm{~km}^{2}$ (future weather conditions). We note an increase in the distribution area of L. camara in Côte d'Ivoire, notwithstanding an increase in temperature predicted by the scenario.

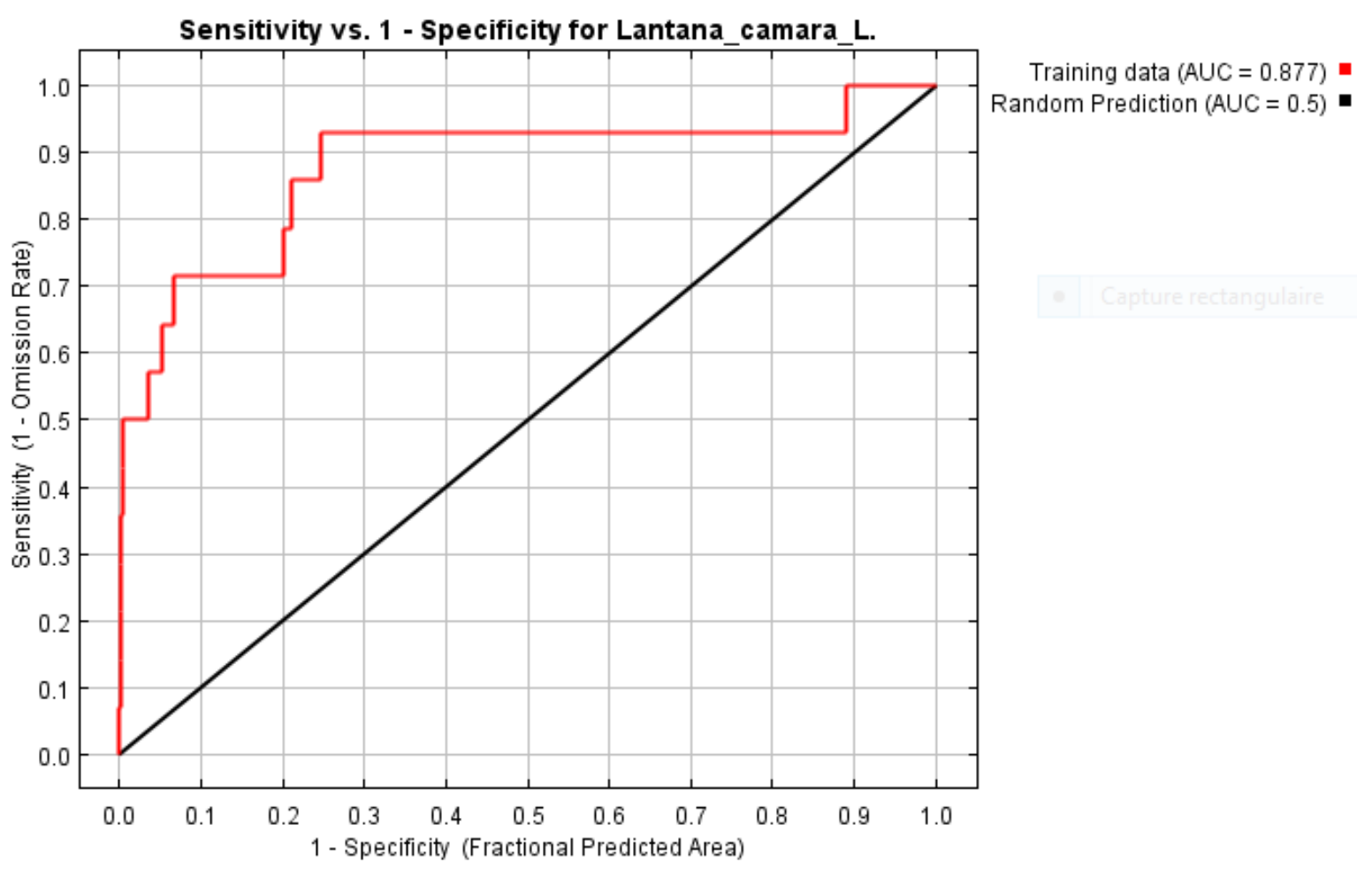

Figure 3 : AUC value for Lantana camara under current climate conditions. 


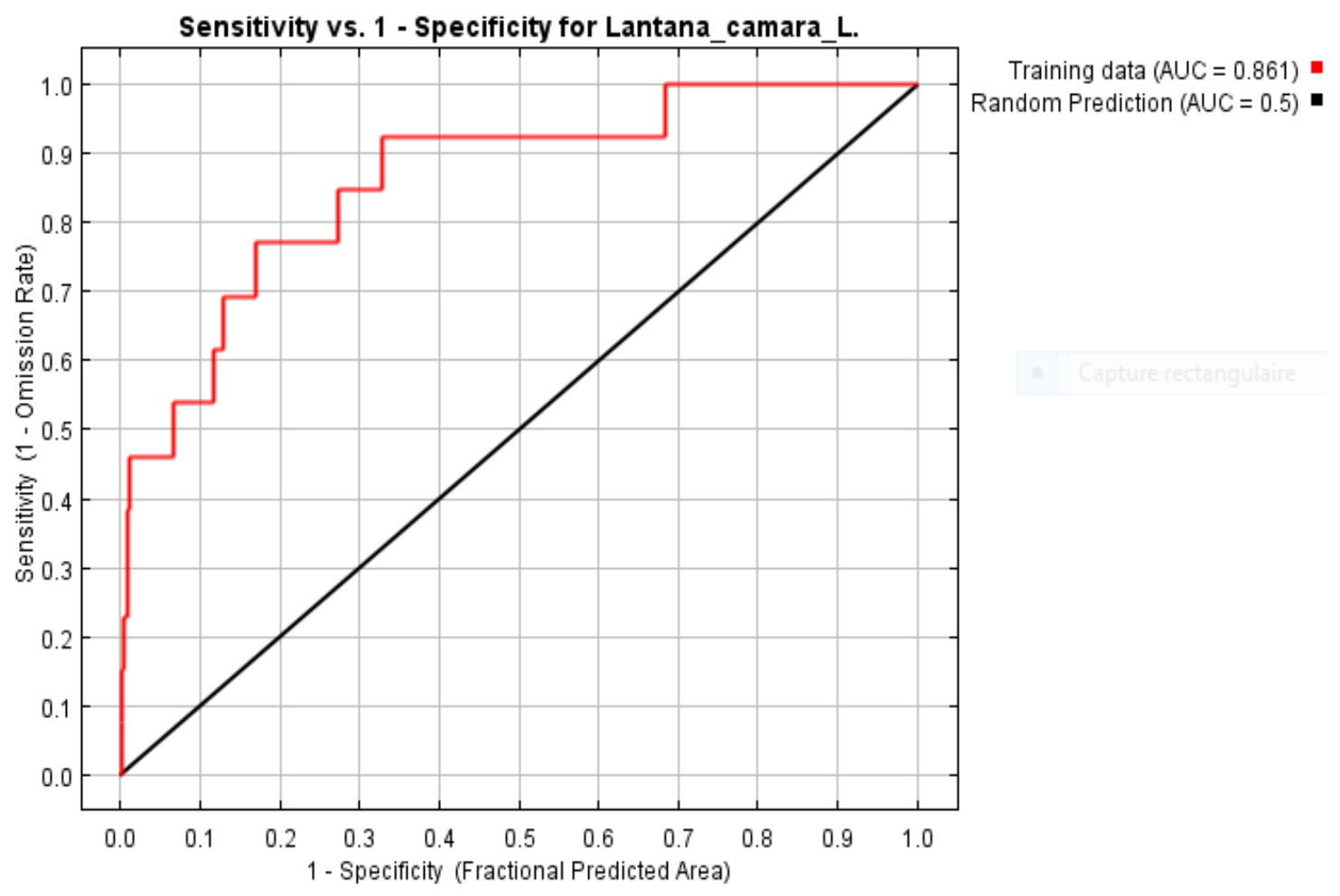

Figure 4 : AUC value for Lantana camara under future climate conditions.

Table 2: Bioclimatics variables used in the study and their percentage contribution in predicting the current and future distribution of Lantana camara.

\begin{tabular}{ccc}
\hline Periods & Bioclimatic Variables & Contribution (\%) \\
\hline \multirow{3}{*}{ Curent } & BIO 7 & $\mathbf{5 6 , 5}$ \\
& BIO 3 & $\mathbf{2 1 , 1}$ \\
& BIO 16 & 11,7 \\
& BIO 8 & 6,2 \\
BIO 18 & 3,2 \\
BIO 5 & 1,3 \\
\hline \multirow{2}{*}{ Future (by 2050) } & BIO 17 & $\mathbf{4 3}$ \\
& BIO 15 & $\mathbf{3 0 , 2}$ \\
& BIO 9 & 14 \\
& BIO 8 & 7,7 \\
& BIO 10 & 3,5 \\
& BIO 18 & 1,5 \\
\hline
\end{tabular}




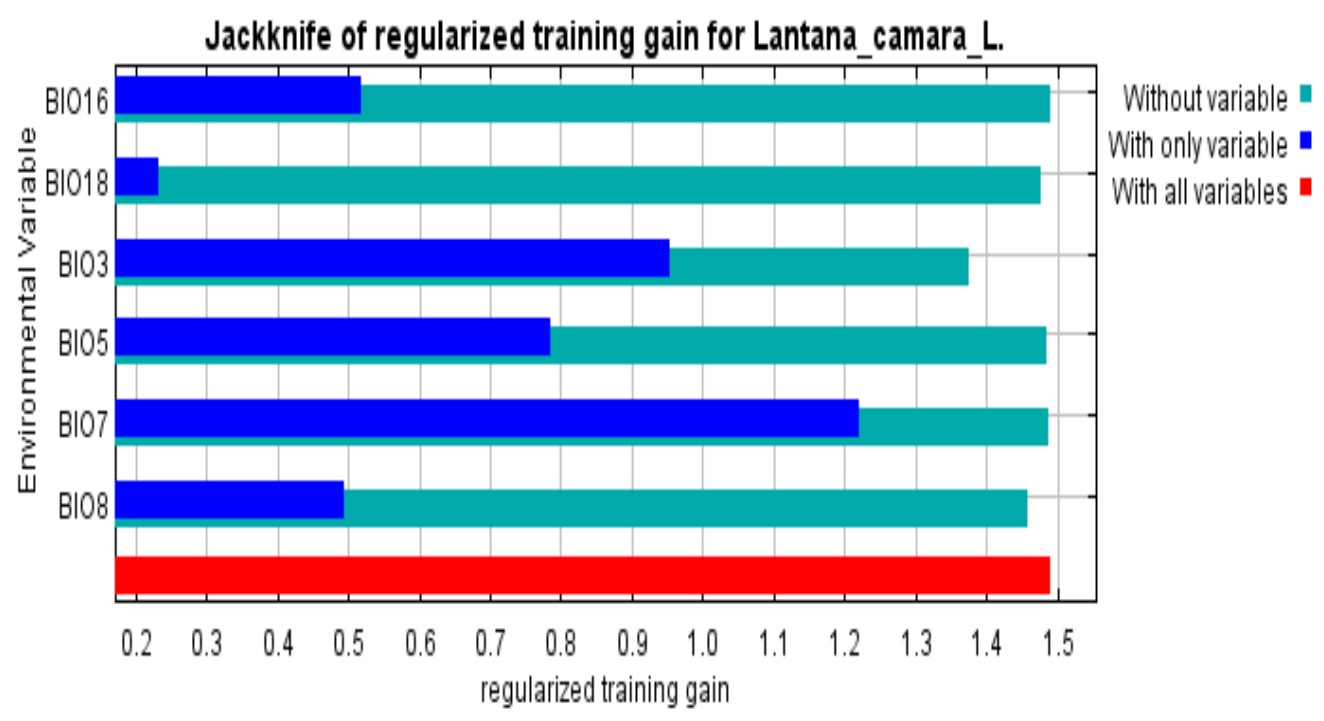

Figure 5: Results of jackknife evaluations of relative importance of predictor variables for Lantana camara Maxent model under the current climate conditions.

Legend: The figure shows the bioclimatic variables on the ordinates and their contributions to model calibration on the abscissa. The green bar shows by how much the total contributions of the variables are reduced if this specific variable is excluded from the analysis. The blue bar shows the proportion of the total contributions of the variables if one variable is used in isolation and the remaining variables are excluded from the analysis. The red bar indicates the performance of the model run with all variables.

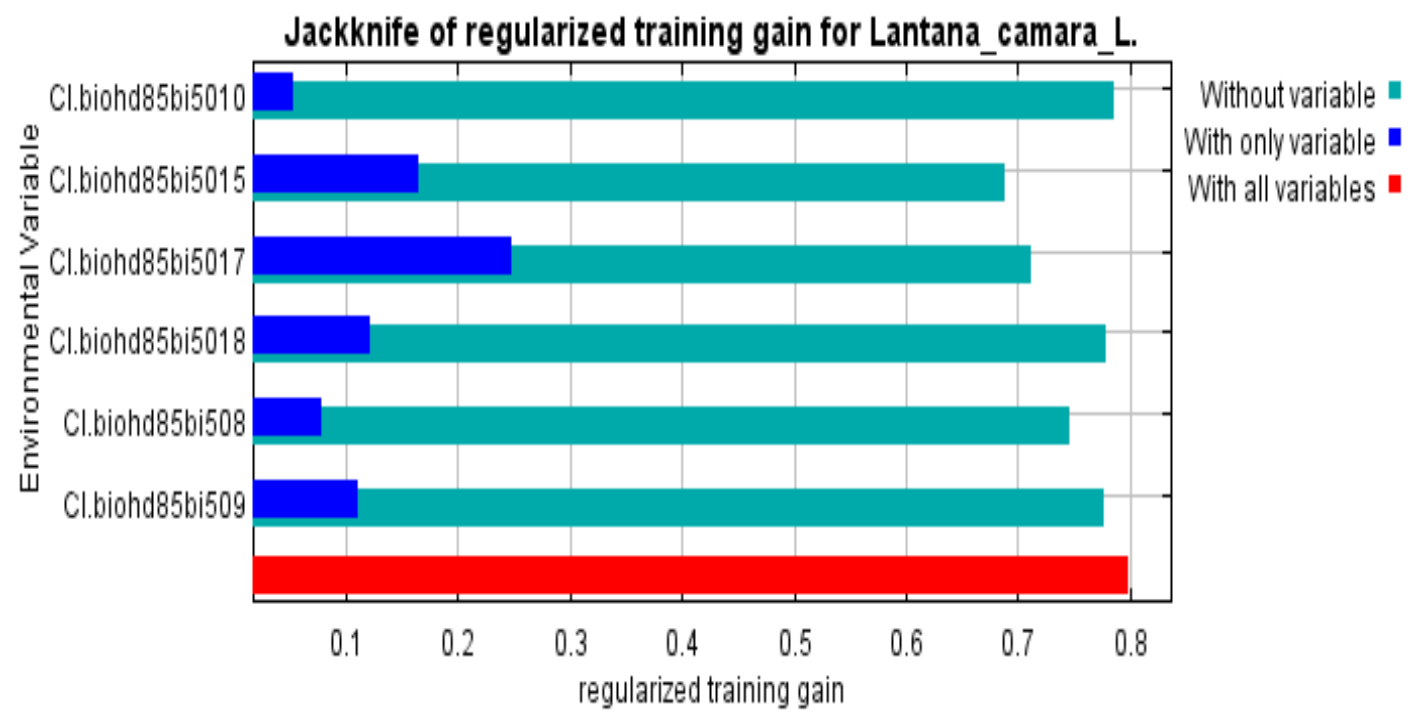

Figure 6: Results of jackknife evaluations of relative importance of predictor variables for Lantana camara Maxent model under the future climate conditions.

Legend: The figure shows the bioclimatic variables on the ordinates and their contributions to model calibration on the abscissa. The green bar shows by how much the total contributions of the variables are reduced if this specific variable is excluded from the analysis. The blue bar shows the proportion of the total contributions of the variables if one variable is used in isolation and the remaining variables are excluded from the analysis. The red bar indicates the performance of the model run with all variables. 

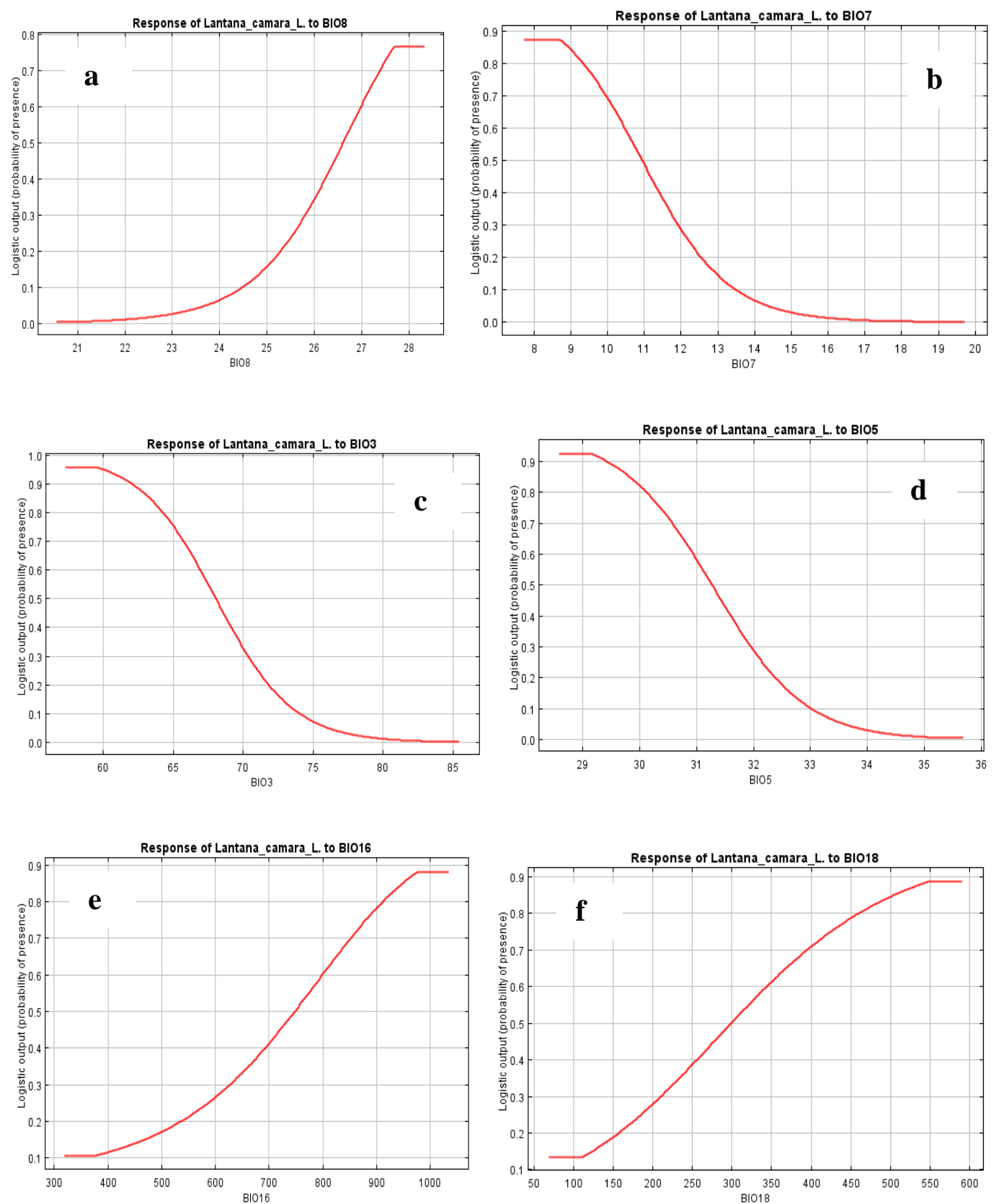

Figure 7: The response curves for the three largest contributing environment variables for Lantana camara under the current climate conditions. 

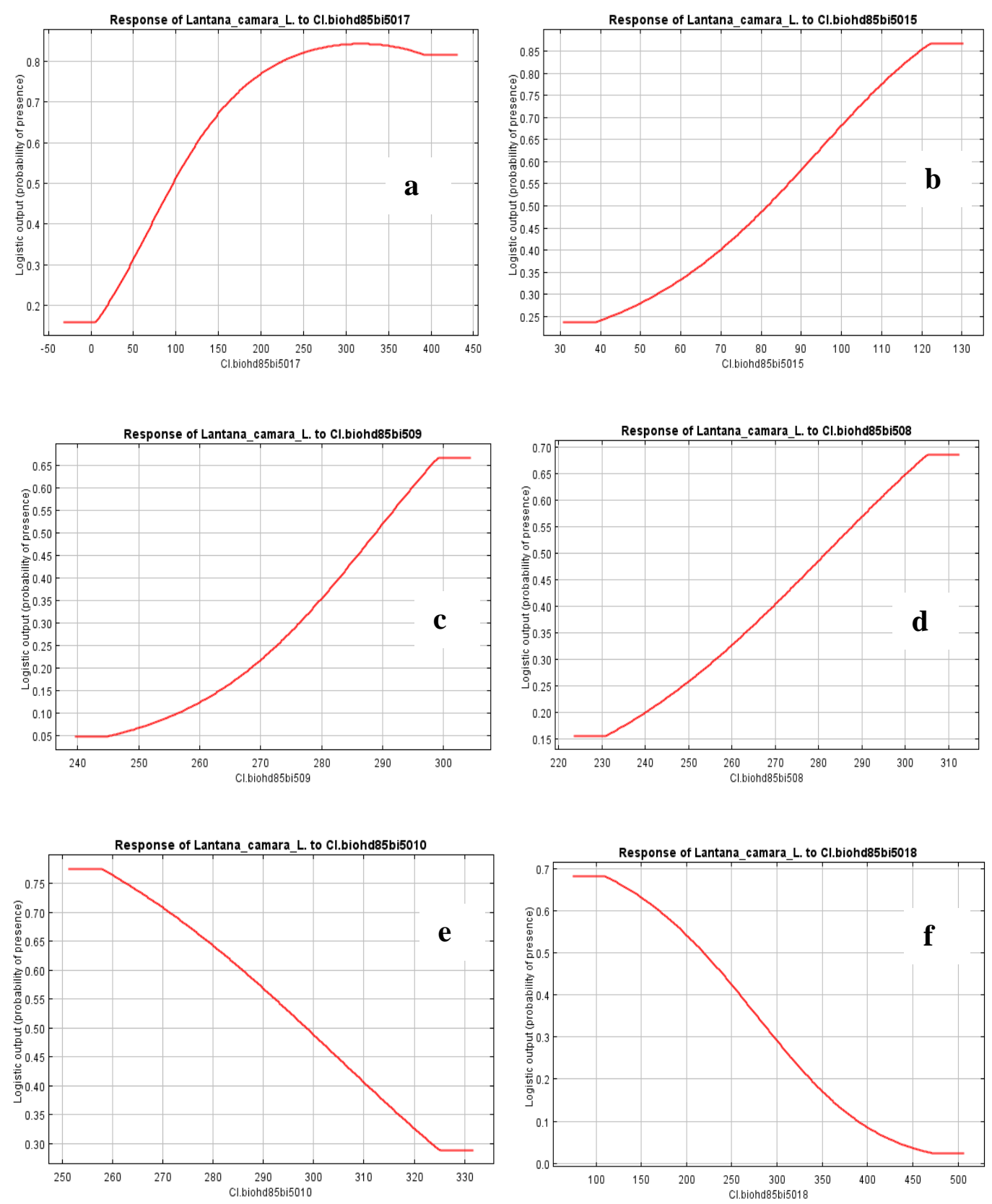

Figure 8: The response curves for the three largest contributing environment variables for Lantana camara under the future climate conditions. 


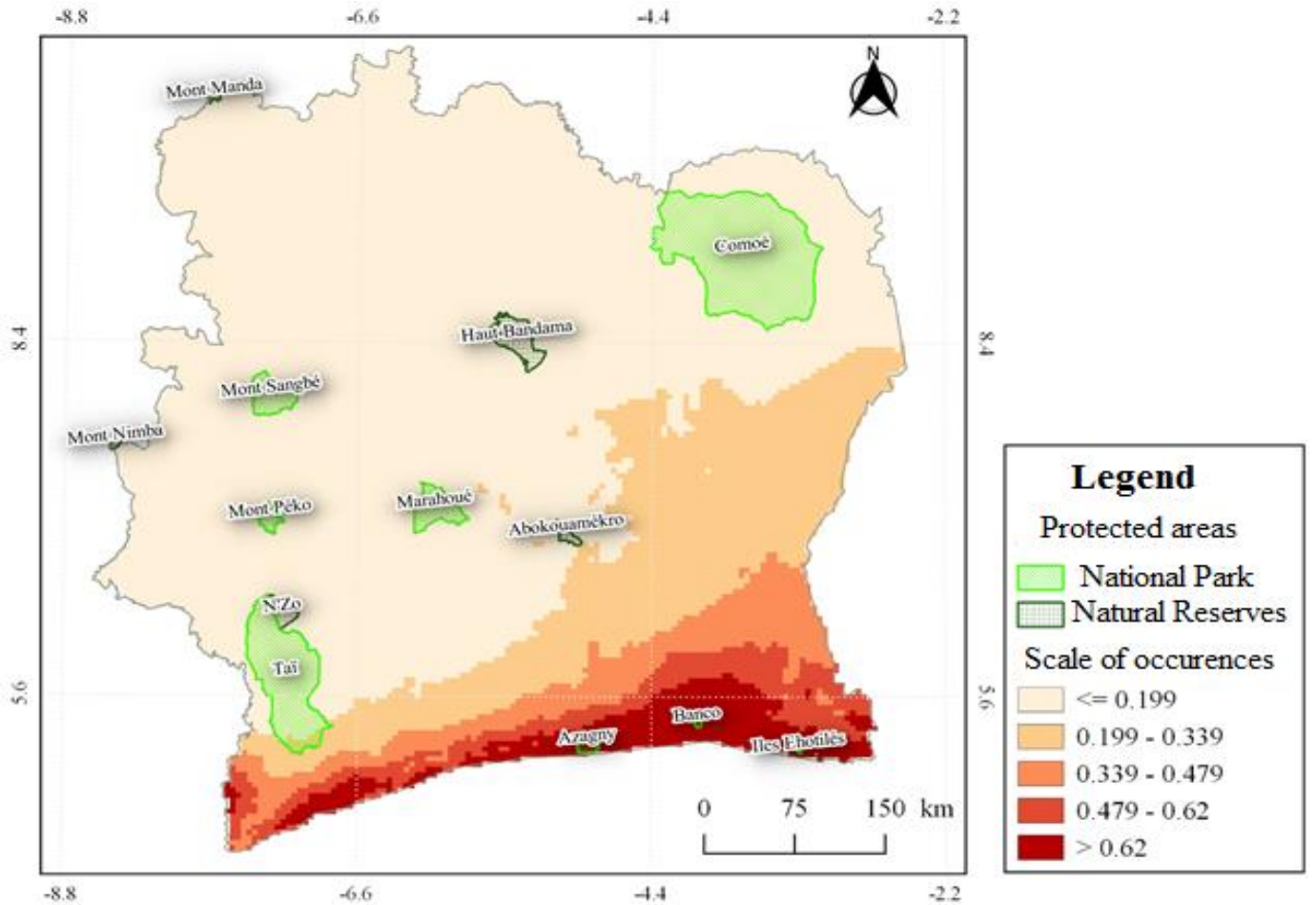

Figure 9 : Current spatial distribution of Lantana camara in Côte d'Ivoire.

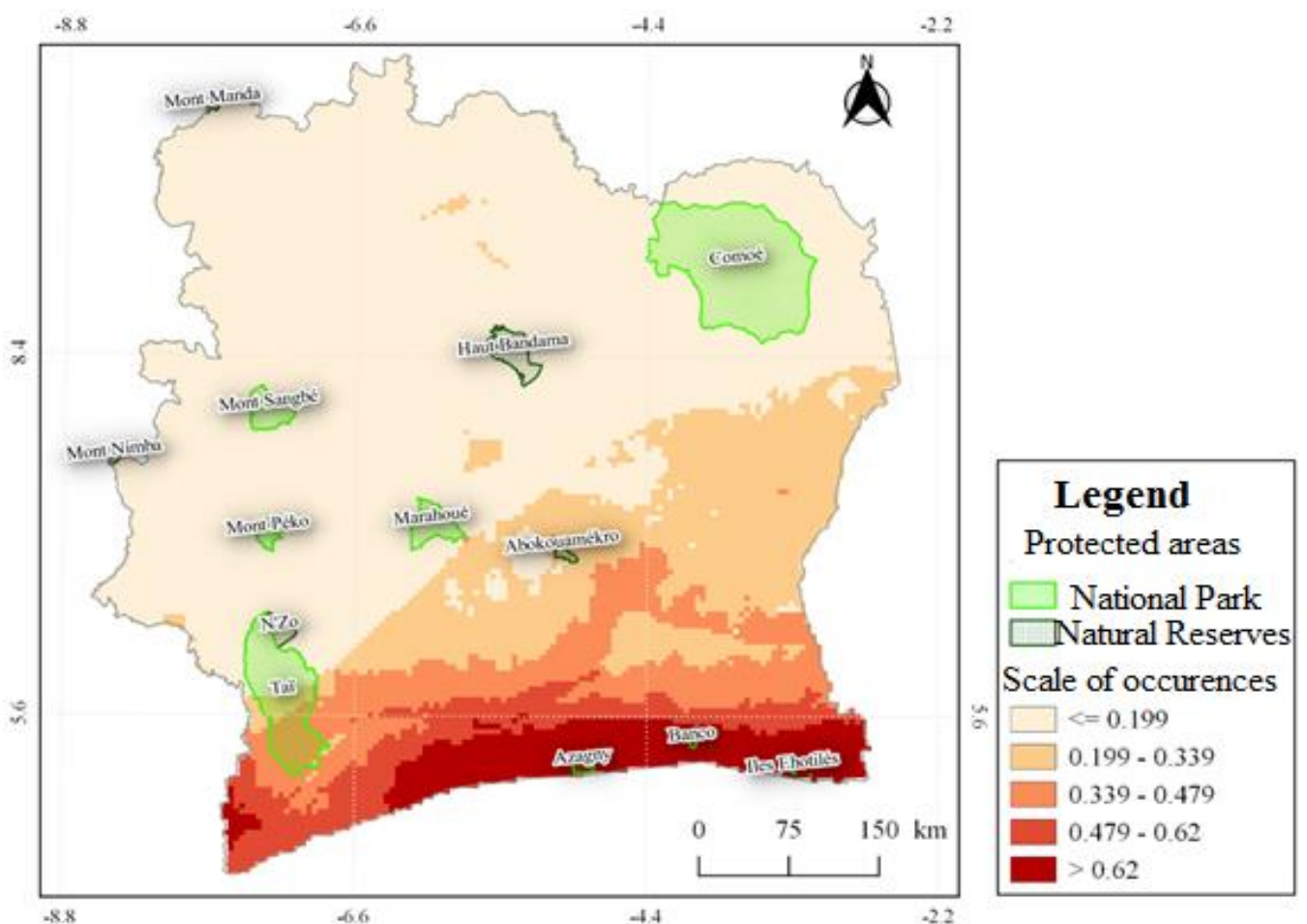

Figure 10: Future potential spatial distribution of Lantana camara in Côte d'Ivoire. 


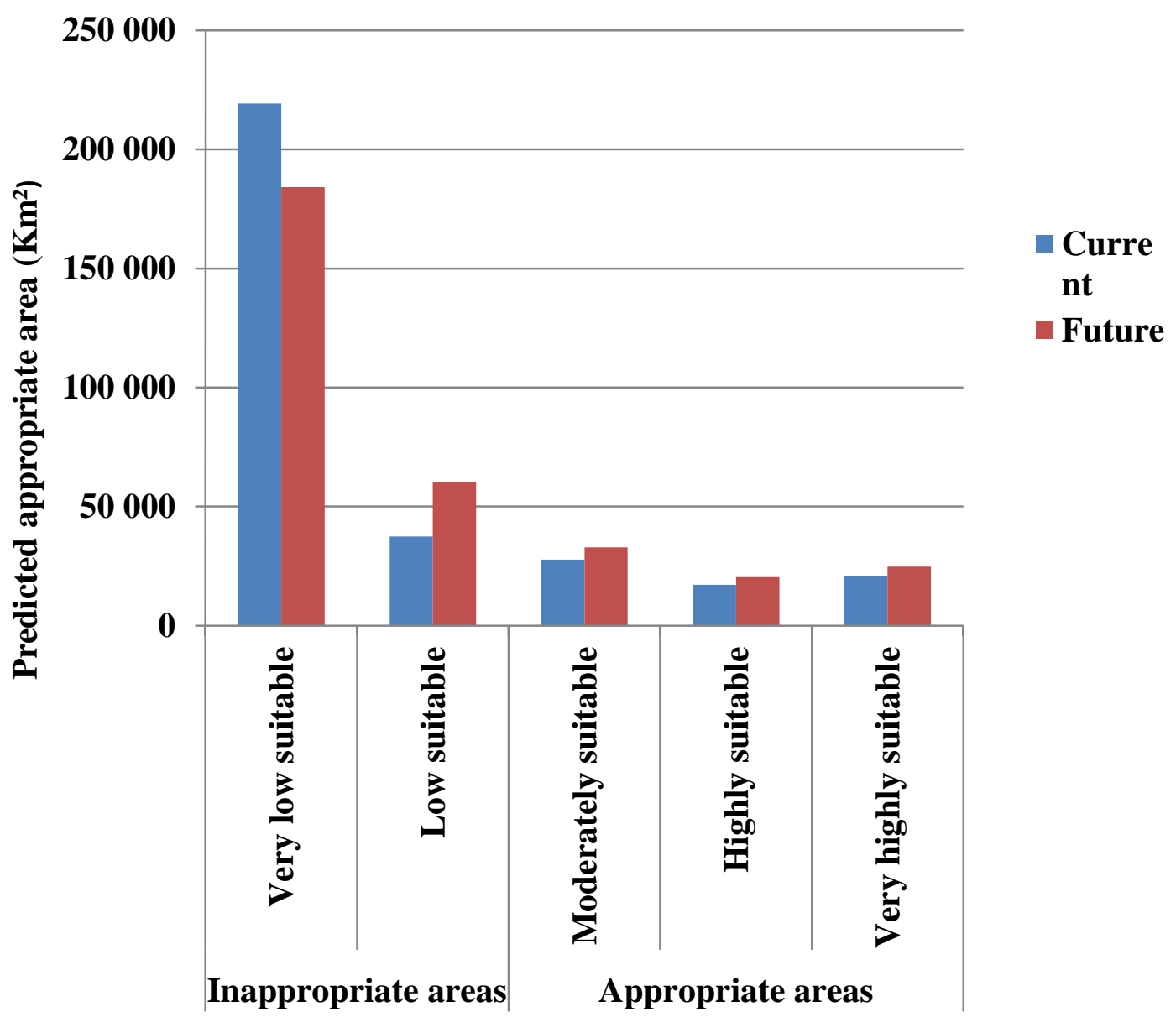

Figure 11: Suitable areas of Lantana camara under present and future climate conditions, as predicted by Maxent based on RCP 8.5 climate model.

Table 3: Variation in the area of potential Lantana camara habitats in Côte d'Ivoire.

\begin{tabular}{ccccccc}
\hline \multirow{2}{*}{ Periods } & \multicolumn{3}{c}{ Appropriate areas } & \multicolumn{3}{c}{ Inappropriate areas } \\
\cline { 2 - 7 } & $\begin{array}{c}\text { Areas } \\
\left(\mathbf{K m}^{2}\right)\end{array}$ & $\begin{array}{c}\text { Percentage } \\
\text { coverage }\end{array}$ & $\begin{array}{c}\text { Change rate } \\
(\mathbf{\%})\end{array}$ & $\begin{array}{c}\text { Areas } \\
\left(\mathbf{K m}^{2}\right)\end{array}$ & $\begin{array}{c}\text { Percentage } \\
\text { coverage }\end{array}$ & $\begin{array}{c}\text { Change rate } \\
(\mathbf{\%})\end{array}$ \\
\hline Current & 65782,40 & 20 & & 256680,70 & 80 & \\
$\begin{array}{c}\text { Future } \\
\text { (By 2050) }\end{array}$ & 78036,05 & 24 & $+18,6$ & & & $-4,8$ \\
\hline \multicolumn{2}{c}{ Sign (-) indicates favorable habitat loss and (+) for a gain. } & & & & \\
\hline
\end{tabular}

Sign (-) indicates favorable habitat loss and (+) for a gain. 


\section{DISCUSSION \\ Quality of the model and bioclimatic variables}

Species distribution models are widely used to determine their habitats on large spatial scales and to produce useful maps to identify priority areas for conservation efforts (Schwartz, 2012). According to Guisan and Thuiller (2005), models are simplified representations of reality, constructed from a limited number of parameters of the real system, deemed relevant to answer a given problem. Indeed, Lahoz-Monfort et al. (2010) point out that one of the models which has proved to be effective in fulfilling all the relevant characteristics is the Maxent model, used more and more by many authors for studies of current and future geographic distribution of invasive species. Other authors have also shown that the maximum entropy model generates significant results in the distribution of species in Côte d'Ivoire (Gnagbo et al., 2015; Asseh et al., 2019; Akaffou et al., 2020). The small size of our sampling guided the choice of this study towards the MaxEnt model because Phillips et al. (2006) demonstrated that this model works with small samples. The best AUC values recorded in this study are similar to those obtained by the works of Saurabh et al. (2019) and Akaffou et al. (2020) in India and in Côte d'Ivoire, indicating excellent predictive quality of the models generated by MaxEnt.

Furthermore, many authors such as Saliou et al. (2014) recommend the use of bioclimatic variables in the execution of models to assess the potential distribution of an invasive species in each territory. Indeed, Djotan et al. (2018) particularly mentioned rainfall and temperature as two bioclimatic variables which play an important role in the geographic distribution of invasive species. According to Guisan and Zimmermann (2000), temperature and precipitation are direct parameters that most affect the distribution of species when the modeling concerns a large area. These observations are in agreement with the results of the present study which demonstrated that temperature and precipitation are the two determining factors in the modeling of the distribution of L. camara at the scale of Côte d'Ivoire. Our results also join the work of Mungi et al. (2018) who demonstrated that temperature and precipitation represent bioclimatic variables which mainly contribute to the execution of models highlighting the spatial distribution of L. camara. Day et al. (2003) and CABI (2020) also noted that climatic descriptors linked to rainfall and temperature play an efficient role in defining the geographic area of L. camara.

\section{Ecological niche and distribution of Lantana camara}

The results of this study are similar to the work of Day et al. (2003) carried out in Australia which showed that L. camara is a species which prefers low temperatures and heavy rainfall. Currently in Côte d'Ivoire, this species is likely to colonize about $20 \%$ of the territory. This zone is defined by a subequatorial climate, characterized by temperatures with low amplitudes, high humidity and abundant precipitation (Avenard et al., 1971; Missa et al., 2015). Indeed, these climatic conditions associated with the penetration of light are at the origin of the proliferation of $L$. camara in many plantations on the Ivorian coast. McGranahan et al. (2007) pointed out that the coastline in general is one of the areas most exposed to biological invasions in the world. According to these authors, the large number of activities carried out on the coast (urbanization, movement of people and goods, etc.) is accompanied by a large influx of propagules of exotic species, introduced accidentally or for purposes ornamental, food, etc.

This study predicts an increase in temperatures and a decrease in precipitation in the 2050s. This result is consistent with that of Riahi et al. (2007) which indicates that the climate of the future will be marked by an endless increase in greenhouse gases, thus contributing more to global warming. The results of this study show that $L$. camara will adapt to this climate change to conquer new territories in Côte d'Ivoire. This statement corroborates the results of Zhang et al. (2014) who report that high temperatures resulting from climate change facilitate the invasion of L. camara in new areas. These observations are 
also consistent with the predictions of McClean et al. (2005) which stipulate that the favorable areas of invasive species are constantly changing due to climate change. Furthermore, the observations of this study have shown that L. camara constitutes a current and future threat to the National Parks and Natural Reserves of Côte d'Ivoire. The same observations were made by IUCN / PACO (2013) in a study in the Bomfobiri Wildlife Sanctuary and Kakum National Park in Ghana. According to this institution, L. camara poses a real threat to the biological diversity of these protected areas.

This study shows that a significant rate of positive change by 2050 in the area probably favors the invasion of this species. According to Toyi et al. (2013), the rate of change in the range of species makes it possible to assess the changes made over time in a defined period. The south of Côte d'Ivoire, identified as an area vulnerable to the invasion of $L$. camara, has recorded a gain in habitats with a high probability of the presence of this species in a forecast of 50 years to come. The explanation given by Qin et al. (2015) is that the physiological tolerance to temperature and precipitation of this species increases the availability of habitats favorable to its proliferation. In addition, the not insignificant increase in the rate of change in the favorable zone is not explained solely for climatic reasons, but could be due to the coastline where most of the country's international trade takes place through the Atlantic Ocean.

\section{Conclusion}

This study made it possible to identify the areas of potential Lantana camara invasion in Côte d'Ivoire, predicted from bioclimatic variables. The results of the modeling indicate that currently $20 \%$ of the national territory is favorable to the proliferation of Lantana camara which prefers environments of low temperatures and heavy precipitation. Notwithstanding the decrease in precipitation predicted by the models by $2050, L$. camara could extend its range to cover $24 \%$ of the national territory, an increase in the rate of change of +18.6 . Protected areas such as the Azagny, Banco National Parks and the Ehotilé
Islands Nature Reserve show current and future distributions with high probability of the species being present. This study constitutes a scientific database that can be used to develop a management strategy for invasive plants in general and for L. camara.

\section{COMPETING INTERESTS}

The authors declare that they have no competing interests regarding the publication of this paper.

\section{AUTHORS' CONTRIBUTIONS}

The various authors of this article have participated in various ways in its conception. FPJP, the lead author, contributed to data collection, analyses, and manuscript writing. OM contributed to the analyses, writing and reading of the paper. NEJA contributed to the development of the maps and surface estimates. MST contributed to the validation of the study protocol, and then proceeded to the reading, improvement and validation of the manuscript.

\section{ACKNOWLEDGEMENTS}

This study received financial support of the African Center of Excellence on Climate Change, Biodiversity and Sustainable Agriculture (CEA-CCBAD) attributed to Mr. Pagny Franck Placide Junior. The authors wish to acknowledge the International Foundation for Science (IFS) through the Carolina Mac Gillavry Award attribute to Dr Marie-Solange TIÉBRÉ (Individual Grant Number J / 5728-1) and the National Center for Agronomic Research of Côte d'Ivoire (CNRA) and the manager of the Marc Delorme station for having authorized the collection of occurrence points.

\section{REFERENCES}

Akaffou SVE, Abrou NEJ, Tiébré MS. 2020. Current and future distribution of Chromolaena odorata (L.) RM. King \& H. Roxb (Compositae) and Hopea odorata Roxb (Dipterocarpaceae) in the Banco national park. IOSR Journal of Pharmacy and Biological Sciences (IOSR-JPBS), 15(2): 06-14. DOI : 10.9790/3008-1502030614 
Asseh EE, Ake-Assi E, Koffi KJ. 2019. Diversité biologique et influence des changements climatiques sur la distribution géographique de quelques espèces d'Acanthaceae en Côte d'Ivoire. International Journal of Biological and Chemical Sciences, 13(2): 676-692. DOI: https://dx.doi.org/10.4314/ijbcs.v13i2.9

Avenard JM, Eldin M, Girad G, Sircoulon J, Touchebeuf P, Guillaumet JL, Adjanohoum E, Perraud A. 1971. Le milieu naturel de la Cote d'Ivoire. Mémoire ORSTOM n 50 , Paris France, $392 \mathrm{p}$.

Baars JR, Heystek F. 2003. Geographical range and impact of five biocontrol agents established on Lantana camara in South Africa. BioControl, 48(6): 743-759.

Bargain A, Fabri M-C. 2016. Guide méthodologique de modélisation predictive d'habitats profonds en Méditerranée. Rapport Convention Cadre Agence de l'Eau RM\&C / Ifremer, Provence Azur Corse, 128p.

Born W, Rauschmayer F, Bräuer I. 2005. Economic evaluation of biological invasions-a survey. Ecological Economics, 55(3): 321-336.

CABI. 2020. Invasive Species Compendium. $\mathrm{CAB}$ International: Wallingford. https://www.cabi.org/isc/datasheet/2977 1

Day M, Wiley CJ, Playford J, Zalucki MP. 2003. Lantana: Current Management Status and Future Prospects. Australian Centre for International Agricultural Research Canberra, ACIAR Monograph: Australia.

Diarrassouba A, Gnagbo A, Célestin Kouakou Y, Campbell G, Tiedoué MR, Tondossama A, Kühl HS, Koné I. 2019. Differential response of seven duiker species to human activities in Taï National Park, Côte d'Ivoire. African Journal of Ecology, 58(1): 58-68.

Djotan AKG, Aoudji AKN, Gbaguidi GCR, Akouehou IG, Ganglo JC. 2018.Vulnérabilité des aires protégées du Bénin à l'invasion de Ageratum conyzoides L. (Asteraceae) en rapport avec les changements climatiques.
European Scientific Journal, 33(14): 3313-330. DOI: 10.19044/esj.2018.v14n33p313

Fandohan AB, Koko IKED, Avocevou-Ayisso C, Gouwakinnou GN, Savi MK, Assogbadjo AE, Kakai RG. 2015. Lantana camara (Verbenaceae): a potential threat to the effectiveness of protected areas to conserve flora and fauna in Benin. Agronomie Africaine, 27(2): 115-126.

Fukushima A. 2013. DiffCorr: an R package to analyze and visualize differential correlations in biological networks. Gene, 518(1): 209-214.

Gbesso FHG, Tenté BHA., Gouwakinnou NG, Sinsin BA.. 2013. Influence des changements climatiques sur la distribution géographique de Chrysophyllum albidum G. Don (Sapotaceae) au Benin. Int. J. Biol. Chem. Sci., 7(5): 2007-2018. DOI: http://dx.doi.org/10.4314/ijbcs.v7i5.18

GISIN. 2011. Réseau mondial d'information sur les espèces envahissantes. Disponible: http://www.niiss.org/cwis438/Websites/ GISINDirectory/SpeciesStatus_TopInvas ives. php?WebSiteID=4. Du 02 févr. 2012.

Gnagbo A, Kpangui KB, Yao CA. 2015. Distribution des épiphytes de Côte d'Ivoire: effets des zones phytogéographiques et des variations pluviométriques. Afrique Science: Revue Internationale des Sciences et Technologie, 11(1): 175-186.

Gooden B, French K, Turner PJ, Downey PO. 2009. Impact threshold for an alien plant invader, Lantana camara L., on native plant communities. Biological Conservation, 142(11): 2631-2641.

Guillaumet JL, Adjanohoun É. 1971. La végétation de la Côte d'Ivoire. In $L e$ milieu naturel de la Côte d'Ivoire, Avenard JM, Eldin E, Girard G, Sircoulon J, Touchebeuf P, Guillaumet JL, Adjanohoun É, Perraud A (eds). ORSTOM: Paris; 157-266.

Guisan A, Zimmermann NE. 2000. Predictive habitat distribution models in ecology. 
Ecological Modelling, 135(2-3): 147186.

Guisan A, Thuiller W. 2005. Predicting species distribution: offering more than simple habitat models. Ecology Letters, 8(9): 993-1009.

DOI:

https://doi.org/10.1111/j.1461-

0248.2005. 00792.x

Hellmann JJ, Byers JE, Bierwagen BG, Dukes JS. 2008. Five potential consequences of climate change for invasive species. Conservation Biology, 22(3): 534-543. DOI: $\quad 10.1111 / \mathrm{j} .1523-$

1739.2008.00951.x

Hernandez PA, Graham CH, Master LL, Albert D.L. 2006. The effect of sample size and species characteristics on performance of different species distribution modeling methods. Ecography, 29: 773-785. DOI: https://doi.org/10.1111/j.09067590.2006.04700.x

Hulme PE, Bacher S, Kenis M, Klotz S, Kühn I, Minchin D, Nentwig W, Olenin S, Panov V, Pergl J, Pyšek P, Roques A, Sol D, Solarz W, Vila M. 2008. Grasping at the routes of biological invasions: a framework for integrating pathways into policy. Journal of Applied Ecology, 45: 403-414. DOI: $10.1111 / \mathrm{j} .1365-$ 2664.2007.01442.x

Imorou IT. 2020. Spatial distribution and ecological niche modelling of Triplochiton scleroxylon K. Schum., in the Guineo-Congolese region of Benin (West Africa). International Journal of Biological and Chemical Sciences, 14(1): 32-44.

DOI: https://dx.doi.org/10.4314/ijbcs.v14i1.4

IPCC. 2013. Climate change 2013: the physical science basis. Contribution of Working Group I to the fifth assessment report of the intergovernmental panel on climate change. Intergovernmental Panel on Climate Change: New York.

Kariyawasam CS, Kumar L, Ratnayake SS. 2019. Invasive Plant Species Establishment and Range Dynamics in Sri Lanka under Climate Change. Entropy, 21(6): 571. DOI : $10.3390 / \mathrm{e} 21060571$
Kassi N, Aké-Assi E, Tiebre MS. 2010. Biodiversité végétale et vitesse de la régénération de la forêt classée de Sanaimbo (Côte d'Ivoire). Sciences \& Nature, 7(2): 195-206.

Kassin KE, Doffangui K, Kouamé B, Yoro G, Assa A. 2008. Variabilité pluviométrique et perspectives pour la replantation cacaoyère dans le Centre Ouest de la Côte d'Ivoire. Journal of Applied Biosciences, 12: 633-641.

Lahoz-Monfort JJ, Guillera-Arroita G, MilnerGulland EJ, Young RP, Nicholson E. 2010. Satellite imagery as a single source of predictor variables for habitat suitability modelling: how Landsat can inform the conservation of a critically endangered lemur. Journal of Applied Ecology, 47(5): 1094-1102. DOI: 10.1111/j.1365-2664.2010.01854.x

Liu CR, Berry PM, Dawson TP, Pearson RG. 2005. Selecting thresholds of occurrence in the prediction of species distributions. Ecography, 28: 385-393. DOI: https://doi.org/10.1111/j.09067590.2005.03957.x

Mandal G, Joshi SP. 2014. The role of habitat types and soil physicochemical properties in the spread of a non nativea shrub Lantana camara in the Doon valley, Western Himalaya, India. Journal of Environmental Geography, 7(3-4): 3142. DOI : $10.2478 /$ jengeo-2014-0010

Maroun L. 2017. Étude de la perception des mauvaises herbes et des espèces végétales exotiques par la population des milieux agricoles en Côte d'Ivoire, l'exemple de Chromolaena odorata, Master, Université de Liège, Liège, 61p.

McClean CJ, Lovett JC, Küper W, Hannah L, Sommer JH, Barthlott W, Termansen M, Smith GF, Tokumine S, Taplin JRD. 2005. Annals of the Missouri Botanical Garden, 92(2): $\quad$ 139-152.

McGranahan G, Balk D, Anderson B. 2007. The rising tide: assessing the risks of climate change and human settlements in low elevation coastal zones. Environment \& Urbanization, 19: 17-37.

Meinshausen M, Smith SJ, Calvin K, Daniel JS, Kainuma MLT, Lamarque J.F, 
Matsumoto K, Montzka SA, Raper SCB, Riahi K, Thomson A, Velders GJM, van Vuuren DPP. 2011. The RCP greenhouse gas concentrations and their extensions from 1765 to 2300 . Climatic change, 109(1-2): 213-241. DOI: 10.1007/s10584-011-0156-z

Missa K, Ouattara D, Koné M, Bakayoko A. 2015. Etude floristique et diversité de la forêt des Marais Tanoé-Ehy (Sud-Est de la Côte d'Ivoire). Journal of Animal \&Plant Sciences, 25(3): 3917-3938.

Mungi NA, Coops NC, Ramesh K, Rawat GS. 2018. How global climate change and regional disturbance can expand the invasion risk? Case study of Lantana camara invasion in the Himalaya. Biological Invasions, 20(7): 1849-1863. 1666-7.

Neuba DF, Malan DF, Koné M, Kouadio YL. 2014. Inventaire préliminaire des plantes envahissantes de la Côte d'Ivoire. Journal of Animal and Plant Sciences (JAPS), 22(2): $\quad 3439-3445$.

N'guessan AE, Akpa YL, Yao N'GO, Kassi JN'D. 2019. Cartographie de la dynamique du couvert végétal de la forêt Classée d'Agbo 1 Côte d'Ivoire. Agronomie Africaine, 31(1): 88-99.

Padalia H, Srivastava V, Kushwaha SPS. 2014. Modeling potential invasion range of alien invasive species, Hyptis suaveolens (L.) Poit. in India: Comparison of MaxEnt and GARP. Ecological Informatics, 22: 36-43. DOI: http://dx.doi.org/10.1016/j.ecoinf.2014.0 4.002

Paini DR, Sheppard AW, Cook DC, De Barro PJ, Worner SP, Thomas MB. 2016. Global threat to agriculture from invasive species. P. Natl. Acad. Sci. U.S.A., 113(27): 7575-7579.

Perrings C, Dalmazzone S, Williamson $\mathrm{MH}$. 2000. The Economics of Biological Invasions. Edward Elgar Publishing: Cheltenham

Phillips SJ, Anderson RP, Schapire RE. 2006. Maximum entropy modeling of species geographic distributions. Ecological Modelling, 190(3-4): 231-259. DOI: 10.1016/j.ecolmodel.2005.03.026
Priyanka N, Joshi PK. 2013. A review of Lantana camara studies in India. International Journal of Scientific and Research Publications, 3(10): 1-11.

Qin Z, Zhang JE, DiTommaso A, Wang RL, $\mathrm{Wu}$ RS. 2015. Predicting invasions of Wedelia trilobata (L.) Hitchc. with Maxent and GARP models. Journal of Plant Research, 128(5): 763-775. DOI: $10.1007 / \mathrm{s} 10265-015-0738-3$

Qin Z, Zhang JE, DiTommaso A, Wang RL, Liang KM. 2016. Predicting the potential distribution of Lantana camara L. under RCP scenarios using ISI-MIP models. Climatic Change, 134(1-2): 193-208. DOI: $10.1007 / \mathrm{s} 10584-015-1500-5$

RGPH. 2014. Recensement Général de la Population et de l'Habitat. Institut National De Statistiques: 49p.

Riahi K, Grübler A, Nakicenovic N. 2007. Scenarios of long-term socio-economic and environmental development under climate stabilization. Technological Forecasting and Social Change, 74(7): 887-935. DOI: 10.1016/j.techfore.2006.05.026

Saliou ARA, Oumorou M, Sinsin AB. 2014. Variabilités bioclimatiques et distribution spatiale des herbacées fourragères dans le Moyen-Bénin (Afrique de l'Ouest). International Journal of Biological and Chemical Sciences, 8(6): 2696-2708.

DOI: http://dx.doi.org/10.4314/ijbcs.v8i6.29

Sangare A, Koffi E, Akamou F, Fall CA. 2009. État des ressources phytogénétiques pour l'alimentation et l'agriculture: Second rapport national. Rapport national sur l'état des ressources phytogénétiques pour l'alimentation et l'agriculture, $64 \mathrm{p}$.

Saurabh P, Neelam R, Govind S, Durgesh P. 2019. Predicting potential invasion of Lantana camara using species distribution modelling in the part of Central Himalaya: Case study of Garhwal Division of Uttarakhand. https://www.researchgate.net/publication /336603516

Schwartz MW. 2012. Using niche models with climate projections to inform conservation management decisions. 
Biological Conservation, 155: 149-156. DOI:

https://doi.org/10.1016/j.biocon.2012.06. 011

Sharma GP, Raghubanshi AS, Singh JS. 2005. Lantana invasion: an overview. Weed Biology and Management, 5(4): 157-165. Sharma GP, Raghubanshi AS. 2010. How Lantana invades dry deciduous forest: a case study from Vindhyan highlands, India. Tropical Ecology, 51(2): 305-316.

Shrestha UB, Sharma KP, Devkota A, Siwakoti M, Shrestha BB. 2018. Potential impact of climate change on the distribution of six invasive alien plants in Nepal. Ecological Indicators, 95: 99-107. DOI: https://doi.org/10.1016/j.ecolind.2018.07 .009

Smith RG, Maxwell BD, Menalled FD, Rew LJ. 2006. Lessons from agriculture may improve the management of invasive plants in wildland systems. Frontiers in Ecology and the Environment, 4(8): 428434.

Taylor S, Kumar L, Reid N, Lewis CR. 2012. Optimal band selection from hyperspectral data for Lantana camara discrimination. International journal of remote sensing, $\mathbf{3 3}(17): \quad 5418-$ 5437. DOI: $10.1080 / 01431161.2012 .661093$

Taylor S, Kumar L. 2013. Potential distribution of an invasive species under climate change scenarios using CLIMEX and soil drainage: a case study of Lantana camara L. in Queensland, Australia. Journal of Environmental Management, 114: 414-422. DOI http://dx.doi.org/10.1016/j.jenvman.2012 .10 .039

Taylor S, Kumar L. 2014. Climate Change and Weed Impacts on Small Island Ecosystems: Lantana camara L. (Magnoliopsida : Verbenaceae) Distribution in Fiji1. Pacific Science, 68(1): 117-133. DOI: http://dx.doi.org/10.2984/68.1.11
Tiébré MS, Pagny FPJ, Kouadio YJC, Gouli Gnanazan ZR. 2018. Etude de la perception de Lantana camara L. (Verbenaceae), une espèce végétale exotique envahissante, par les populations riveraines des cocoteraies du Sud-Est de la Côte d'Ivoire. REB PASRES, 3(3): 68-77.

Toyi MS, Barima YSS, Mama A, André M, Bastin JF, De Cannière C, Sinsin B, Bogaert J. 2013. Tree plantation will not compensate natural woody vegetation cover loss in the Atlantic

Department of Southern Benin. Tropicult., 31: 62-70.

Traoré K, Péné CB. 2016. Étude phytoécologique des adventices dans les agroécosystèmes élaeicoles de la Mé et de Dabou, en basse Côte d'Ivoire. Journal of Applied Biosciences, $\quad$ 104(1): 10005-100018.

UICN. 2000. Lignes directrices de l'UICN pour la prévention de la perte de la diversité biologique causée par les espèces exotiques envahissantes. UICN: Commission de sauvegarde des espèces.

UICN/PACO. 2013. Plantes invasives affectant les aires protégées d'Afrique de l'Ouest : gestion pour la réduction des risques pour la biodiversité. UICN/ PACO: Ouagadougou.

Vanderhoeven S, Branquart E, Grégoire JC, Mahy G. 2007. Les invasions biologiques. Forêt. Nature, 89: 24-43.

Yi YJ, Zhou Y, Cai YP, Yang W, Li ZW, Zhao X. 2018. The influence of climate change on an endangered riparian plant species: the root of riparian Homonoia. Ecol. Indic., 92: 40-50. DOI: https://doi.org/10.1016/j.ecolind.2017.05 .004

Zhang Q, Zhang Y, Peng S, Zobel K. 2014. Climate warming may facilitate invasion of the exotic shrub Lantana camara. PloS one, 9(9): e105500. DOI: 10.1371/journal.pone.0105500 